\title{
Correlations between historical climate data and incidents of common bunt in Spanish wheat, 1755-1801
}

Fernando Martínez Moreno, Ignacio Solís, Mariano Barriendos \& ERNESTO TEJEDOR

KEYWORDS: Maldà Anomaly, pro serenitate rogations, Tilletia, Triticum.

JEL CODES: N0, N5, Q0, Q1.

$F$

rom 1755 to 1801 in Spain, many articles and reports were written about common bunt, a seed-borne plague that was difficult to control at the time. The objective of the study is to better understand this plague and the relationship between historical rainfall indexes and years of higher reported outbreaks. We compared documentary sources on extreme rain events and annual series of wheat prices in four locations (Murcia, Seville, Toledo, and Zamora) with data from articles about the bunt plague. Increased severity of common bunt in wheat coincided with a concentration of such events, during a period of severe climatic irregularity known as the Maldà Anomaly. However, the cause-and-effect relationship for proxies of historical weather, price volatility and bunt plague was only significant in Seville. A complementary factor that explains the abundance of literature was access to agricultural articles and books from France, where the common bunt also existed. The first experiments to understand the plague and how to control it were performed there. These events are framed in the Spanish Enlightenment and early physiocratic ideas advocating the importance of agriculture in maintaining the wealth of a country. 


\section{Correlación entre datos de clima histórico y ataques de tizón del trigo en España, 1755-1801}

\section{PALABRAS CLAVE: Anomalía Maldà, rogativas pro serenitate, Ti- lletia, Triticum.}

\section{CÓDIGOS JEL: N0, N5, Q0, Q1.}

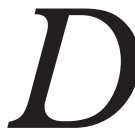

urante 1755-1801 existen bastantes artículos e informes sobre el tizón del trigo en España, una plaga trasmitida por semilla y de difícil control en esa época. El objetivo de este trabajo es conocer la importancia de esta plaga en esta época, incluida su relación con indicadores históricos de lluvia y los años descritos con mayores ataques. Para ello, se relacionaron registros documentales de lluvias extremas y series anuales de precios de trigo en cuatro localidades (Murcia, Sevilla, Toledo y Zamora) con datos de las descripciones de epifitias de tizón de los artículos. La mayor severidad del tizón del trigo coincidió con una concentración de episodios de lluvia excesiva, en un periodo de fuerte irregularidad climática conocido como anomalía Maldà, aunque la relación causa-efecto entre indicadores de tiempo atmosférico histórico, precio del grano y la plaga solo fue significativa en Sevilla. Otro factor complementario que explica la abundancia de estos artículos sobre el tizón fue una conexión con artículos y libros de agricultura procedentes de Francia, donde también existía el tizón, y donde se realizaron los primeros experimentos para entender la plaga y su control. Todas estas circunstancias se engloban dentro del periodo de la Ilustración española y en el inicio de las ideas fisiocráticas que propugnaban la importancia de la agricultura para mantener la riqueza de un país.

Received: 2019-03-22 - Revised: 2020-09-17 - Accepted: 2020-09-21

Fernando Martínez Moreno [orcid.org/0000-0001-5852-1851] is assistant professor of the University of Seville. Address: Department of Agroforestry Sciences of the Technical School of Agricultural Engineers (ETSIA), University of Seville, ctra de Utrera, km 1, 41013 Sevilla (Spain).E-mail:fernan@us.es

Ignacio Solís [orcid.org/0000-0003-4807-1070] is assistant professor of the University of Seville. Address: Department of Agroforestry Sciences of the Technical School of Agricultural Engineers (ETSIA), University of Seville, ctra de Utrera, km 1, 41013 Sevilla (Spain).E-mail: isolis@us.es

Mariano Barriendos [orcid.org/0000-0001-9220-1245] is associated professor of the University of Barcelona. Address: Department of History and Archaeology, University of Barcelona, Montalegre, 6, 08001 Barcelona (Spain).E-mail:mbarriendos@ub.edu

Ernesto Tejedor [orcid.org/0000-0001-6825-3870] is a postdoctoral research associate. Address: Department of Atmospheric and Environmental Sciences, University at Albany (SUNY), Albany (United States). E-mail: etejedor@albany.edu 


\section{INTRODUCTION}

In the Spain of the late $18^{\text {th }}$ century cereals occupied circa 7.6 million ha (the same amount was fallowed), while vine and olive tree acreage were 1.6 and 0.9 million ha, respectively (Rivero, 2013: 37). Wheat was the main cereal (and crop) in Spain with an acreage ranging between 4-4.5 million ha and an annual production of 1.8-2 million t.Yields were low (about $450 \mathrm{~kg} / \mathrm{ha}$ ) due to the limited precipitation, the poor soils of the great Meseta (plateau of Spain), and the scant fertilization (Rivero, 2013: 102, 116). The supply was frequently insufficient since bread consumption was very high (about $0.75 \mathrm{~kg}$ per person and day) in the $18^{\text {th }}$ and $19^{\text {th }}$ centuries (Rivero, 2013:215-16). Sowing (siembra) time was around October-November while harvesting (cosecha) took place between June (southern Spain) and July (northern Spain). Wheat was sown close to almost all villages and towns of Spain, but especially in the basins of the great rivers such as the Guadalquivir (where Seville is located), Tagus (where Toledo is located), Duero (where Zamora is located), and Segura (where Murcia is located) (Royo \& Briceño-Felix, 2011: 125-26).

Wheat has a multitude of potential plagues. Rust outbreaks were often reported in antiquity. Stem rust spores were retrieved from excavations in Israel in the late Bronze Age (3,300 BP) (Kislev, 1982), while Romans had a divinity for wheat rust named Robigus and a ceremony called Robigalia that was celebrated on April 25. According to Zadoks (2013: 226-28) plague and pest outbreaks in past times were more frequent at the local level (scale $10 \mathrm{~km}$ ), less frequent regionally (scale $100 \mathrm{~km}$ ), and very rarely continentally (scale $1,000 \mathrm{~km}$ ), and were caused by different organisms, especially large insects and small mammals (locusts, rodents, rabbits, etc.). Little is known, however, about the presence or damage caused by wheat plagues and pests in the past in Spain. It seems that several agronomic practices of antiquity somehow buffered plant plague build-up, such as crop rotations, low seed rate, limited fertilization, and a noteworthy genetic diversity within and between wheat landraces (Zadoks, 2013: 226-28). Still, there were occasional favourable epidemiological conditions that resulted in severe outbreaks that damaged wheat. There are not many references to wheat plagues in the $17^{\text {th }}$ and $18^{\text {th }}$ centuries in Spain, although it seems that the pests locusts (Alberola, 2012; García Torres, 2015; Muñoz, 2019) and granary weevils (Azcárate, 1997: 185) and the fungi of common bunt (Azcárate \& Maldonado, 1992), and rusts (mainly stem rust, although yellow and leaf rust were also present) (Martínez Moreno \& Solís, 2019) were the main wheat plagues.

Common bunt (or bunt) is a seed- and soil-borne plague caused by the fungal species Tilletia tritici and T. laevis. Common bunt spores are in the soil or the seed and infect wheat seedlings. The fungus develops inside the wheat plant and permeates the young spikelet and the wheat kernel where new spores are formed, replacing the interior of the 
kernel with a black mass of spores that are easily disseminated to clean grains at harvest time, and also to the soil. It has been associated with wheat cultivation since the beginning of recorded history (Wilcoxson \& Saari, 1996: 12-3). Common bunt produces several negative effects, the most obvious being decreased wheat production. In addition, bunt spores contaminate the wheat seed to be used for sowing the next season, further propagating the plague, while the quality of bread produced with even slightly bunted flour is poor with an unpleasant rotten fish odour (Dubin \& Duveiller, 2011: 1163). In the period 1755-1801, there were abundant reports and articles about common bunt outbreaks in different parts of Spain (Azcárate \& Maldonado, 1992).

The effect of rain and dew on cereal plagues has been observed since antiquity. Aristotle (384-322 BCE) mentioned that the damage caused by rust was exacerbated by humidity, and Theophrastus (371-287 BCE) wrote that rust was a process brought about by sunshine following dew (Chester, 1946: 3). Rainfall increases moisture in the air raising relative humidity on the plant surface and, like temperature, boosts plant plague development. Many plagues caused by fungi develop from spores that germinate in the presence of high humidity in the air or a film of water covering the leaf or other plant parts. High soil moisture and low temperatures around the time of seedling emergence (November, December, January) are linked to greater severity of common bunt (Benlloch, 1948). Furthermore, high moisture and rainfall during wheat anthesis (heading), which corresponds to March and April, have also been correlated to bunt (Allen et al., 2009; Workneh et al., 2008). In the late $18^{\text {th }}$ century, Spain (especially the east side) experienced highly unstable hydrometeorological conditions known as the Maldà Anomaly, which was a period during the Little Ice Age (Oliva et al., 2018) in which the characteristics of the Mediterranean climate were exaggerated, alternating between drought and heavy rain, floods, snowfall, and storms at sea. The ten-year period from 1785-95 had the highest frequency of floods and droughts. Other regions of the Mediterranean Rim, such as Sicily, the Balkans, and the Adriatic coast, also experienced climatic anomalies at this time (Barriendos \& Llasat, 2003).

The objective of this article is thus to provide insight into the outbreaks of common bunt in wheat between 1755 and 1801, including the relationship with historical rainfall indexes, years of higher severity, impact on production, and control measures of the time.

\section{METHODOLOGY}

Several information sources regarding the period 1755-1801 were consulted and analyzed to meet the objectives of this study. First was information from the historical common bunt 
TABLE 1

\section{Characteristics of the reported common bunt outbreaks of 1755-1801 in Spain}

\begin{tabular}{|c|c|c|c|}
\hline Outbreak & Location (province or region) & Source & Journal \\
\hline - & - & Anonymous (1755) & Discursos mercuriales \\
\hline- & - & Anonymous (1765) & Semanario económico \\
\hline $\begin{array}{l}1783,1784 \\
1785,1786\end{array}$ & (Adrados) Segovia & Sainz (1786) & $\begin{array}{l}\text { Actas y memorias de la Real Sociedad Eco- } \\
\text { nómica de los Amigos del País de la provin- } \\
\text { cia de Segovia }\end{array}$ \\
\hline 1785 & Segovia & Alcalá (1786a) & $\begin{array}{l}\text { Actas y memorias de la Real Sociedad Eco- } \\
\text { nómica de los Amigos del País de la provin- } \\
\text { cia de Segovia }\end{array}$ \\
\hline- & Segovia & Alcalá (1786b) & $\begin{array}{l}\text { Actas y memorias de la Real Sociedad Eco- } \\
\text { nómica de los Amigos del País de la provin- } \\
\text { cia de Segovia }\end{array}$ \\
\hline- & - & Anonymous (1790) & Memorial literario \\
\hline 1790 & $\begin{array}{l}\text { Pamplona region (Navarra), } \\
\text { Murcia region, Granada region, } \\
\text { Alcarria region (Guadalajara), } \\
\text { Madrid region, La Sagra region } \\
\text { (Toledo), Talavera de la Reina }\end{array}$ & Lucas (1790) & Memorial literario \\
\hline - & $\begin{array}{l}\text { Herencia (Ciudad Real), Maru- } \\
\text { gán (Segovia) }\end{array}$ & Valle (1790) & Memorial literario \\
\hline - & - & Lucas (1794) & Memorial literario \\
\hline - & Madrid & Higueras (1797) & $\begin{array}{l}\text { Memorias de la Real Sociedad de Amigos } \\
\text { del País de Madrid }\end{array}$ \\
\hline - & $\begin{array}{l}\text { (Ardales) Málaga, Tijola (Alme- } \\
\text { ría) }\end{array}$ & Benitez (1797) & $\begin{array}{l}\text { Semanario de agricultura y artes dirigido a } \\
\text { los párrocos }\end{array}$ \\
\hline - & - & Vaux (1797) & $\begin{array}{l}\text { Semanario de agricultura y artes dirigido a } \\
\text { los párrocos }\end{array}$ \\
\hline- & Jaca (Huesca) and Huesca & Clavero (1797) & $\begin{array}{l}\text { Semanario de Agricultura y Artes dirigido a } \\
\text { los párrocos }\end{array}$ \\
\hline- & - & Anonymous (1797) & $\begin{array}{l}\text { Semanario de agricultura y artes dirigido a } \\
\text { los párrocos }\end{array}$ \\
\hline- & Lagunilla (Logroño) & Palacios (1798) & $\begin{array}{l}\text { Semanario de agricultura y artes dirigido a } \\
\text { los párrocos }\end{array}$ \\
\hline- & - & Anonymous (1799) & $\begin{array}{l}\text { Semanario de agricultura y artes dirigido a } \\
\text { los párrocos }\end{array}$ \\
\hline $\begin{array}{l}1785,1786 \\
1787\end{array}$ & - & Vallín (1801) & $\begin{array}{l}\text { Semanario de agricultura y artes dirigido a } \\
\text { los párrocos }\end{array}$ \\
\hline
\end{tabular}


reports. These provided information about specific seasons and locations of common bunt outbreaks, control methods, and even the impact of the plague. Second were geoclimatic descriptions of the four studied locations. Third were data of extreme rain events and of drought events. The former indicated possible periods favourable to common bunt outbreaks that were checked against the written reports of the time. Fourth was wheat grain price volatility. The annual series of wheat prices at three out of the four locations were used to analyze the relationships between seasons with extreme rain events, seasons with common bunt outbreaks, and seasons with rising wheat prices. Fifth was information on the political and economic situation of the late $18^{\text {th }}$ century in Spain.

\subsection{Common bunt reports and articles}

Seventeen reports and articles on common bunt in different Spanish journals of the time were found and consulted during the studied period (see Table 1). The basis of the search was an article by Azcárate and Maldonado (1992) describing an abundance of reports and articles on common bunt at that time in Spain. Most documents are now available online.

\subsection{Description of the studied locations}

Four locations (Murcia, Seville, Toledo, and Zamora) were selected for being important wheat areas in Spain in the past, and for having abundant documentary information on extreme rain events. The characteristics of selected locations are presented in Table 2. All locations are cities close to a river (Segura river at Murcia, Guadalquivir at Seville, Tagus at Toledo, and Duero at Zamora) and surrounded by river basins with deep wet clay soil prone to wheat cultivation in a Mediterranean environment. Toledo and Zamora are on the Spanish Plateau at an elevation close to $600 \mathrm{~m}$ while Murcia and Seville are near coastal areas at elevations near sea level (42 and $11 \mathrm{~m}$ respectively). Therefore, the climates of Toledo and Zamora are more extreme than those of Murcia and Seville. Seville is the warmest location with a mean temperature of $36.0^{\circ} \mathrm{C}$ during the warmest month and $5.7^{\circ} \mathrm{C}$ during the coldest month (data from 1981-2010). Zamora was the coldest location with a mean temperature of $30.4{ }^{\circ} \mathrm{C}$ during the warmest month and $0.9{ }^{\circ} \mathrm{C}$ during the coldest month (data from 1981-2010). 
TABLE 2

Geoclimatic characteristics of the selected locations of the present study

\begin{tabular}{lllll}
\hline Characteristics & Murcia & Seville & Toledo & Zamora \\
\hline River basin & Segura & Guadalquivir & Tagus & Duero \\
Climate (current) & ${ }^{1}$ & Csa & BSk & BSk \\
Temp. min. coldest month & 4.7 & 5.7 & 1.3 & 0.9 \\
Temp. (mean) & 18.6 & 19.2 & 15.8 & 13.1 \\
Temp. max. warmest month & 34.2 & 36.0 & 34.6 & 30.4 \\
Height (m above sea level) & 42 & 11 & 516 & 649 \\
Annual precipitation $(\mathrm{mm})^{2}$ & 297 & 539 & 342 & 379 \\
Precipitation days $(>1 \mathrm{~mm})^{2}$ & 37 & 51 & 54 & 64 \\
Geographic coordinates & $37^{\circ} 59^{\prime} 10^{\prime \prime} \mathrm{N}$ & $37^{\circ} 23^{\prime} 00^{\prime \prime} \mathrm{N}$ & $39^{\circ} 52^{\prime} 00^{\prime \prime} \mathrm{N}$ & $41^{\circ} 29^{\prime} 56^{\prime \prime} \mathrm{N}$ \\
& $1^{\circ} 07^{\prime} 49^{\prime \prime} 0$ & $5^{\circ} 59^{\prime} 00^{\prime \prime} 0$ & $4^{\circ} 02^{\prime} 00^{\prime \prime} 0$ & $5^{\circ} 45^{\prime} 20^{\prime \prime} 0$ \\
\hline
\end{tabular}

Note: climate after Köppen-Geiger classification (Kottek et al., 2006). Csa: temperate, dry and hot summer; BSh: arid, steppe, hot; BSk: arid, steppe, cold.

Sources: data by Agencia Estatal de Meteorología (Murcia, 1984-2010; Seville, 1981-2010; Toledo, 19822010; Zamora, 1981-2010) (AEMET, 2019).

\subsection{Data of extreme rain events (mainly pro serenitate rogations)}

Extreme rain events between 1755 and 1801 were recorded to see rainfall patterns during the studied time frame (the period November-May, which encompasses the wheat growing season). Extreme rain data were extracted from private and administrative documentary sources. The main type of information was the pro serenitate rogations, ceremonies organized by the Catholic Church to pray for the lessening or cessation of heavy and continuous rains, which can serve as proxy data for past climates as they were recorded in reliable administrative documents generated by public institutions, with a date and a description of the state of affairs. The rogations' documentary records are preserved in local authorities' administrative archives, such as the books of accounts of City Councils (ayuntamientos) and Cathedral Chapters (cabildos catedralicios), where all quotidian affairs of the respective institutions were recorded and preserved daily. The availability of the records of rogations was continuous and systematic in the studied period (Rodrigo \& Barriendos, 2008). The rogation act was a response that involved several agents. The heavy and continuous rains greatly worried farmers, so they communicated the situation to their guild leaders, who in turn requested the town authorities for an intervention. If the decision was positive and rogation was to be initiated, a delegation would be sent to the ecclesiastical authorities. The Church could receive advice, but it was responsible for the organization of the ceremonies which included date setting, liturgical procedure, and type of prayer (Martín Vide \& Barriendos, 1995). 
Additional information was also obtained from private documentary sources, such as dietaries and chronicles. Bibliographical sources also provided information about extreme weather events, mostly collected by local historians. Most events recorded in the pro serenitate rogation ceremonies and other sources correspond to prolonged rains that could have caused problems for the wheat crop. Flash floods, torrential rains of short duration, and snow melting processes were discarded because they usually are produced by convective atmospheric processes that had a very local effect. Nevertheless, in all cases this additional information offered a more complete scenario for rainfall patterns, facilitating the interpretation and characteristics of rainfall and identifying large-scale persistent rainfall or small-scale convective events. After the authors first applied the methodology of searching for pro serenitate rogations (Barriendos, 1997), other efforts were focused on reconstruction and characterization of rainfall patterns in the Iberian Peninsula using the abovementioned historical proxies (Rodrigo \& Barriendos, 2008).

All this information was collected in a spreadsheet by location and year. Since most of the events had a date, each one was assigned a month, hence the temporal resolution was monthly. Events were classified in three levels according to their severity and consequences: a) pro serenitate rogations or simple river flood; b) extraordinary flooding with disturbing but not destructive river overflows; c) catastrophic flooding and destructive overflows. Methodologies for data collection on documentary and bibliographical sources, cataloguing and classification of information were developed and improved in different steps to guarantee the reliability and homogeneity of data and indices (Barriendos \& Martín Vide, 1998; Barriendos et al., 2014). Two common bunt indexes were made from the written reports and the excessive rain events:

a) References bunt index: a general index (the same for all four locations) in which a value was given to every season, which was drawn from references to specific years in the consulted reports on common bunt. Out of the period 17551801 (0); within the period of references to common bunt (1755-1801) (0.5); references to bunt outbreak years $(1770,1781-99)(1)$; references to more specific bunt outbreak years $(1783-87,1790)(1.5)$.

b) Rainfall bunt index (from the extreme rain events): catastrophic floodings (0.5); extraordinary flooding, disturbing but not destructive river overflows (0.75); pro serenitate rogations or periods of persistent rains (1). Excessive rain events from November, December, and January received a value +1 , since higher common bunt severity is positively correlated with rainfall at sowing time (Benlloch, 1948). 


\subsection{Drought years (pro pluvia rogations)}

Drought years were extracted from pro pluvia rogations (ceremonies organized by the Church during droughts to pray for rain) in the studied period 1755-1801. Information about these rogations were drawn from the same sources as the pro serenitate rogations and were divided into three classes: a) low-level pro pluvia rogations (displayed in churches), signifying minor drought conditions that nonetheless prompted some action; $b$ ) medium-level pro pluvia rogations (displayed in public spaces) signifying serious drought with an impact on crops; c) maximum-level pro pluvia rogations, signifying catastrophic drought with irreversible effects such as major harvest losses resulting in a subsistence crisis (Martín Vide \& Barriendos, 1995; Domínguez Castro et al., 2012; Tejedor et al., 2019).

\subsection{Wheat price volatility}

Wheat price annual series were used as a proxy for wheat production. They have a higher reliability with respect to the tithe documentation, mostly taken from rented land that did not properly reflect the production during the studied period (Llopis et al., 2018). Data series with prices from Seville (1726-1800) were obtained from Ponsot (1986: 52021). Wheat price series from Murcia (1762-1800) were taken from Llopis and Sotoca (2005), while wheat prices from Zamora (1726-88) were drawn from Llopis and Jerez (2001). Wheat prices at Toledo could not be found. The indexes of the cost of living were extracted from Llopis et al. (2009). Seville's and Murcia's prices were referenced to the cost of living in Seville while Zamora prices were referenced to the cost of living of nearby Palencia. Since wheat prices at Seville and Zamora were taken in January while harvest time was June-July, they indicate (as proxy data) the wheat production of the previous season. Murcia prices, which were taken in July, were used as a proxy of the just-harvested season. In Seville, barley prices were also available for most of the studied period (Ponsot, 1986: 514-15). Barley, unlike wheat, is minimally affected by the common bunt. A correlation analysis between wheat price and the two bunt indexes was performed at Seville, Murcia, and Zamora. The correlation coefficient of Spearman -more appropriate since the lack of normality of the data- and the P-value -to assess the statistical significance of the correlations- were calculated. 


\section{RESULTS AND DISCUSSION}

\subsection{Weather and common bunt at specific locations}

In the period 1755-90, several journals raised the subject of the common bunt (Discursos mercuriales, Semanario económico, Memorias de la Real Sociedad de Amigos del Pais, Memorial literario, Semanario de agricultura y artes dirigido a los párrocos). The seventeen collected reports were short documents of various origins. Some were translations from articles published in France, others were authored by people from villages in contact with the problem (including priests and anonymous writers), while still others seem to have been written by people from large urban societies (e.g. Real Sociedad de Amigos del Pais) to address issues of national concern. In general, these reports and articles showed great concern regarding the common bunt, and at the same time were looking for explanations and solutions. During 1783-87 there were reports of common bunt outbreaks at specific places such as Segovia (Alcalá, 1786a, 1786b; Sainz, 1786; Valle, 1790), and in 1790 this plague was reported at different locations throughout Spain (Navarra, Murcia, Toledo, Granada, Guadalajara, Madrid, etc.) (Lucas, 1790). In general, it seems that the common bunt was scattered all over the wheat areas of Spain (see Figure 1).

\section{FIGURE 1}

Map with selected locations from which extreme rain events were recorded, river names cross those locations, and locations and regions mentioned in the common bunt outbreak of 1755-1801

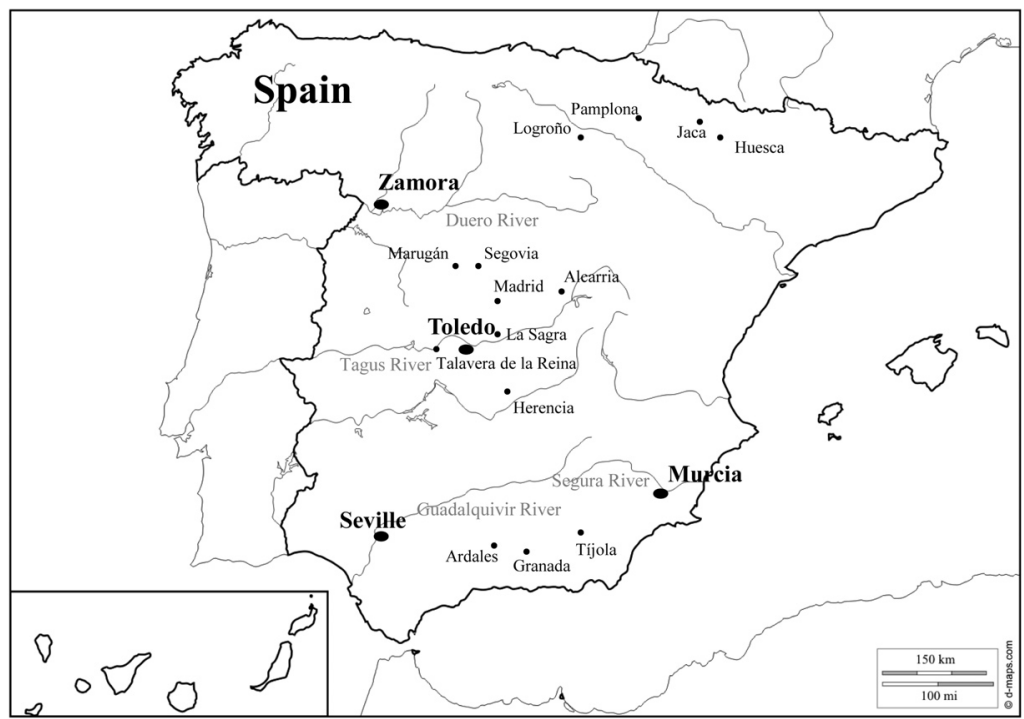

Source: locations where the presence of common bunt was recorded were taken from Table 1 . 
TABLE 3

Description by year and wheat growing months of extreme rain events (as determined by pro serenitate rogations, among other types of evidence) and drought events (pro pluvia rogations) in Spain, 1755-1801

\begin{tabular}{|c|c|c|c|c|c|}
\hline Month & Murcia & Seville & Toledo & Zamora & No. \\
\hline January & $\begin{array}{l}1763(1), 1768(1), 1777(1), 1778(3) / \\
1758(1), 1759(2), 1773(1), 1774(2), \\
1775(2), 1776(2), 1780(2), 1782(1), \\
1798(2)\end{array}$ & $\begin{array}{l}1758(3), 1763(2), 1768(2), \\
1769(1), 1772(1), 1778(3), \\
1784(1), 1785(1), 1786(2), \\
1787(2), 1789(2), 1791(2), \\
1792(2), 1796(2), 1800(2) / \\
1793(1)\end{array}$ & $\begin{array}{l}\text { 1777(1), } \\
\text { 1778(1)/ } \\
1780(1)\end{array}$ & $1787(1)$ & $\begin{array}{l}22 / \\
11\end{array}$ \\
\hline February & 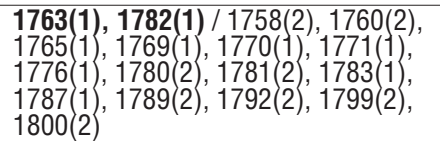 & $\begin{array}{l}1777(2), 1786(1), 1795(2), \\
1800(2) / 1770(2), 1779(1), \\
1781(1), 1790(2), 1793(2)\end{array}$ & $\begin{array}{l}1763(1) \\
1770(1) \\
1780(1) \\
1798(1)\end{array}$ & $1788(2)$ & $8 / 23$ \\
\hline March & $\begin{array}{l}\text { 1794(1), } 1759(1), 1760(2), 1765(1), \\
1766(1), 1767(2), 1770(2), 1774(1), \\
1777(1), 1780(2), 1781(2), 1783(2), \\
1784(1), 1787(2), 1789(2), 1790(2), \\
1791(2), 1792(2), 1793(2), 1799(2), \\
1800(2), 1801(2)\end{array}$ & $\begin{array}{l}1772(2), 1784(1), 1785(1), \\
1786(3), 1800(1) / 1775(1), \\
1780(1), 1781(2), 1789(1), \\
1790(2), 1791(2), 1793(2), \\
1798(1)\end{array}$ & $\begin{array}{l}1780(1) \\
1790(1) \\
1791(2) \\
1798(1)\end{array}$ & $1781(2)$ & $6 / 34$ \\
\hline April & $\begin{array}{l}1790(1), 1794(1), 1797(1) / 1766(1), \\
1770(2), 1772(2), 1780(2), 1782(1), \\
1783(2), 1786(1), 1791(2), 1792(2), \\
1793(2), 1798(2)\end{array}$ & $\begin{array}{l}\text { 1777(1), } \mathbf{1 7 8 6 ( 2 ) ,} \mathbf{1 8 0 0 ( 1 ) /} \\
1757(2), 1780(2), 1794(1)\end{array}$ & $\begin{array}{l}1764(1), \\
1765(1) \\
1773(1) \\
1775(2), \\
1779(1) \\
1780(2), \\
1791(2)\end{array}$ & $\begin{array}{l}1757(1), 1767(1), \\
1773(2), 1775(1), \\
1779(2), 1780(2), \\
1783(2), 1789(1), \\
1794(2), 1797(2)\end{array}$ & $6 / 32$ \\
\hline May & $1758(1) / 1786(1)$ & $\begin{array}{l}1774(1), 1786(2), 1795(1) / \\
1780(2)\end{array}$ & $\begin{array}{l}1788(1), \\
1764(2), \\
1773(1), \\
1775(2), \\
1779(1), \\
1787(2), \\
1793(2), \\
1794(1), \\
1797(2)\end{array}$ & $\begin{array}{l}1757(3), 1761(2), \\
1764(2), 1765(1), \\
1767(3), 1770(2), \\
1772(2), 1775(2), \\
1776(2), 1783(2), \\
1787(2), 1793(2), \\
1794(1)\end{array}$ & $5 / 23$ \\
\hline June & 1792(1), 1797(1), 1798(1) & 1773(1) & - & 1788(1) / 1793(2) & $5 / 1$ \\
\hline November & $\begin{array}{l}\mathbf{1 7 5 6}(1), 1777(1), 1783(1) / 1757(2), \\
1758(2), 1759(1), 1760(2), 1762(2), \\
1764(1), 1765(2), 1768(2), 1770(2), \\
1773(2), 1774(2), 1775(1), 1778(2), \\
1779(1), 1780(2), 1781(2), 1785(1), \\
1787(2), 1788(1), 1789(1), 1792(1), \\
1795(2), 1796(2), 1800(2)\end{array}$ & $\begin{array}{l}1796(1), 1799(2) / 1764(1), \\
1765(1), 1770(1), 1779(2), \\
1781(2), 1793(2), 1794(2)\end{array}$ & $\begin{array}{l}1764(1) \\
1765(1) \\
1779(2) \\
1780(1) \\
1781(2)\end{array}$ & $1764(1)$ & $5 / 37$ \\
\hline December & $\begin{array}{l}\text { 1783(1), 1796(1), 1801(1) / 1757(2), } \\
1758(2), 1773(2), 1774(2), 1779(2), \\
1780(2), 1781(2), 1787(2), 1792(1), \\
1800(2)\end{array}$ & $\begin{array}{l}1764(1), 1768(1), 1783(3), \\
1784(1), 1786(2), 1796(3)\end{array}$ & $\begin{array}{l}1777(1) / \\
1780(1)\end{array}$ & - & $\begin{array}{l}10 / \\
11\end{array}$ \\
\hline Total & $20 / 90$ & 39 / 25 & $5-31$ & $3-26$ & $\begin{array}{l}67 / \\
172\end{array}$ \\
\hline
\end{tabular}

Notes: year of extreme rain event in bold print; year of pro pluvia rogation in normal print.

Intensity of the extreme rain event between brackets: (1) pro serenitate rogations or simple river flood; (2) extraordinary flooding with disturbing but not destructive river overflows; (3) catastrophic flooding and destructive overflows. Intensity of the drought event between brackets: (1) simple pro pluvia rogation (minor drought conditions that nonetheless prompted some action); (2) complex and public pro pluvia rogation (severe drought with impacts on crops); (3) pro pluvia rogation of maximum level (catastrophic drought with irreversible effects such as major harvest losses resulting in a subsistence crisis).

Sources: Barriendos and Martín Vide (1998); Barriendos et al. (2014). 
Common bunt was favoured by the unstable weather and many extreme rain events of the Maldà Anomaly period. This fact is confirmed by many studies correlating that plague with increased soil moisture and low temperature after sowing, at the time of emergence and establishment of the seedling (about December-January) (Benlloch, 1948), but also at wheat heading or espigado (late March and early April) (Smiley, 1997; Workneh et al., 2008; Allen et al., 2009). The period 1755-1801, which encompasses the Maldà Anomaly, accounted for 66 extreme rain events (39 at Seville, 20 at Murcia, five at Toledo, and two at Zamora), which is a greater number than expected if records were evenly distributed in the period 1700-1850 (41.4 events, therefore more than 50\% higher than expected, data not shown) (Table 3). Most events were recorded in January (22) and December (19), two of the months most conducive to the plague. But drought years and therefore the corresponding pro pluvia rogations were also frequent at this time (also depicted in Table 3). Of the 172 rogations of this kind recorded in the four locations more than half were noted in Murcia (90), followed by Toledo (31), Zamora (26), and Seville (25). Murcia had these rogations in all years of the studied period except 1761, 1763, 1794, and 1797. November (37), March (34), and April (32) were the months with the most pro pluvia rogations. Generally, the period $1755-82$ was dry, with a lack of precipitation in late winter and early spring. During 1783-88 extreme rain events and cold winters were frequents, and from 1789 to 1801 weather returned to the Maldà Anomaly's general conditions (strong and short periods of rain within an ongoing drought).

\subsubsection{Period 1755-1782}

In general, this period was characterized by severe drought with isolated rainy years. In six years, pro pluvia rogations were celebrated at all four locations (1764, 1765, 1770, 1779, 1780 , and 1781). However, the years $1763,1777,1778$ had pro serenitate rogations celebrated at Murcia, Seville, and Toledo. References to common bunt in those years could not be found, but Sainz pointed out the presence of common bunt in 1770 in Segovia province while performing some observations with the help of some local farmers: [...] with the desire to investigate the cause, and that of 1770, due to the fact that this vice [the common bunt] had become particular with the seeds of four farmers, [...]. This author also addressed 1781 and 1782 as years that bunt spoiled his seed: [...] But in the year of 81, a kind of humid mist ${ }^{1}$ that came from the north on the day that the seed was cleaned, was enough cause to infect the grain of the immediate harvest in a large part: the same accident occurred in the year of 82, falling some waters at time to clean the seed, [...] (Sainz, 1786: 328, 332).

1. When writing the Spanish word niebla (mist) this author (and others) refers indistinctly to both mist and common bunt. 


\subsubsection{Period 1783-1788}

The year 1783 marked a change in the atmospheric patterns of Spain. In June the eruption of the Laki volcano (Iceland) altered the atmosphere of Europe (and North America), including Spain, causing a drop in temperature, increasing torrential and persistent rainfall, and provoking agricultural losses (Alberola, 2012; Barriendos \& Gómez, 1997). This period accounted for 19 extreme rain events in the four studied locations, while only 5.9 events would be expected according to an even distribution in the period 1700-1850. In addition, this period was relatively free of pro pluvia rogations with only 16, mostly in Murcia (Murcia, 12; Seville, 0; Toledo, 1; Zamora, 3) (Table 3). The Guadalquivir river overflowed its banks in December 1783, causing enormous problems in Seville (Alberola \& Arrioja, 2020). From summer 1783 to April 1784 there were catastrophic deluges through the east and south of Spain, affecting Catalonia, Aragon, Valencia, and Andalusia (Alberola et al., 2018). October 1783 saw three consecutive floodings of Segura river, which passed by Murcia (García Torres, 2017). The winter of 1783-84 was very hard, and 1784 is considered one of the coldest years in the recorded history ofWestern Europe (Tejedor et al., 2017; Muñoz, 2019). Between 1785 and 1789 strong rains fell constantly all over Spain, including Andalusia. In 1786, the rain was persistent in Seville from January to May, and pro serenitate rogations were celebrated each month. The year 1787 continued to be characterized by unstable weather in most of Spain. In January 1787, a pro serenitate rogation was celebrated at Zamora while strong rains were recorded at Seville.

The years 1783-86 were reported by Sainz (1786), and 1785, 1786, and 1787 were cited by Vallín (1801) as years of common bunt surges. This period is key to this study. Sainz (1786: 332) wrote that all the harvest of year 83 was covered by mist [(i.e. common bunt) and that] in the years of 84 and 85, in which, especially in this last one, the mist in this location and nearby areas has been very general [Segovia], and Vallín (1801:357) stated that in the years of 1785, 86, and 87 there was common bunt in many parts [of Spain]. Interestingly, common bunt outbreaks in France were also reported in 1785 and 1787 (Zadoks, 2008: 161). The year 1788 was not included among the years with specific mentions to bunt, but it was reported to be a cold winter and an extremely raining autumn (García Torres, 2017) with overflows of several rivers, including the Duero as it crossed Zamora (Alberola, 2015). By June, pro serenitate rogations were recorded at Zamora and at Toledo. Beginning in September 1788, hail-laden downpours affected the east of the country, including the town of Orihuela (20 km apart from Murcia) which was affected by a Segura river overflow in November (García Torres, 2017). 


\subsubsection{Period 1789-1801}

The years 1789 and 1790 were dry with many pro pluvia rogations celebrated all over Spain, especially in the east (Cremades, 2017; García Torres, 2017). Starting in 1789, Spain experienced a thermal recovery in which droughts were frequent, accompanied by harsh winters and short wet springs (Alberola \& Arrioja, 2020). Nonetheless, 1790 has been counted a year of common bunt outbreaks in this study since Lucas (1790:277) pointed out that in the present year common bunt has possibly removed a seventh part of the wheat harvest. Most likely, inoculum from previous years were still either in the soil or in contaminated grain since it has been proved that in a field infected with common bunt, the inoculum remains active in that soil for several years (Wilcoxon \& Saari, 1996: 1-2). Anyway, in January 1789 and 1791, pro serenitate rogations were recorded at Sevi1le. The year 1793 saw pro pluvia rogations at the four locations, while in 1794, 1798, and 1797 rogations of this class were recorded at three sites.

Although several years of higher severity have been pointed out, the common bunt was present every season in Spain. As Vallín (1801: 356) pointed out I dare to say that I have observed nature in this same act in the years of 1785, 86 and 87 and we have always had common bunt in this country I inhabit.

\subsection{Wheat price volatility and common bunt}

Wheat price volatility was a proxy for the wheat production of the previous season at Seville and Zamora. Many factors can influence wheat price, including grain importation, immobilization of the harvest, taxes, storage capacity, municipal regulations, etc., but production is generally the main factor. Excess of water in the soil, excessive temperatures at heading, plagues, and pests all have negative impacts on wheat production.

At Seville, where a more complete set of data was obtained, wheat prices (more than $28 \mathrm{pts} / \mathrm{hl}$, pesetas per hectolitre, Table 5) may indicate that wheat production was low during the seasons of 1762-63, 1763-64, 1767-68, 1768-69, 1776-77, 1784-85, 1785-86, and 1791-92. At this location alone, wheat prices correlated significantly and positively with the rainfall bunt index $(r=0.44, \mathrm{P}=0.00)$ (Table 4 , Figure 2$)$. Therefore, high prices might have been caused by a factor linked to rainfall, such as common bunt. In fact, farmers around Seville area traditionally did not like heavily rainy years since many plagues built up and wheat production could decrease. On the other hand, Toledo and Zamora have a drier and more extreme climate (typical of the Spanish plateau), making them less inclined to plagues, and rainy years favour higher production. It has been explained that 
common bunt was over all the wheat areas of Spain, but some areas (like Seville) were more prone to common bunt infections than others (such as Toledo or Zamora). Rust is another wheat disease favoured by high rainfall. Interestingly, Alcalá Galiano wrote about the wheat rust in Spain in 1786, and the Guadalquivir Valley (where Seville rests) has been an area prone to wheat rust (Alcalá, 1786b; Martínez Moreno \& Solís, 2019). Anyway, the references to rust were far less numerous than those to common bunt during the studied time (a ratio of seventeen to one), and Seville also had good conditions for common bunt (consistent rainy season, clay soils capable of storing large amounts of water, mild winter and spring temperatures, and low altitude) (Wilcoxon \& Saari, 1996: 2). In the cited seasons of high wheat prices (i.e., low production), Seville also had a high ratio of wheat prices to barley prices (above 2), and a high rainfall index (more than 0.75) (see Figure 2). Barley is not much affected by common bunt, therefore a high ratio of wheat to barley prices may give us a clue about the possible presence of common bunt. In part this may be due to the fact that farmers usually cultivated barley in sandy or silty soils, which makes it less susceptible to plague, while wheat is sown in the river valley (Guadalquivir Valley in this case) where heavy rain is more conducive to plagues.

\section{TABLE 4}

Correlation between wheat price (referred to the cost of living) and two bunt indexes in Seville (1726-99), Murcia (1762-1800), and Zamora (1726-87)

\begin{tabular}{llll}
\hline & Wheat price Seville & Wheat price Murcia & Wheat price Zamora \\
\hline References bunt index & $0.203^{\mathrm{a}}$ & -0.092 & 0.158 \\
(Seville / Murcia / Zamora) & $(74)^{\mathrm{b}}$ & $(39)$ & $(62)$ \\
& $0.083^{\mathrm{b}}$ & 0.569 & 0.217 \\
\hline Rainfall bunt index & 0.440 & -0.005 & 0.120 \\
(Seville / Murcia / Zamora) & $(74)$ & $(39)$ & $(62)$ \\
& 0.000 & 0.977 & 0.349 \\
\hline
\end{tabular}

a Correlation coefficient of Spearman.

${ }^{\mathrm{b}}$ Number of analyzed cases (years).

${ }^{\mathrm{c}} \mathrm{P}$ value. Values lower than 0.05 indicate a significant correlation.

Source: data for statistical analysis were taken from Tables 3, 5, 6, and 7.

In the Murcia series (1762-1800) (Table 6) the seasons 1774-75, 1775-76, 1789-90, and 1793-94 had both high wheat price prices (more than $29.5 \mathrm{rs}$./fa, reales por fanega, referenced to the cost of living) and high rainfall bunt index. Wheat prices of Zamora (172688) are depicted in Table 7. The seasons 1760-61, 1761-62, 1768-69, 1777-78, 1778-79, $1779-80,1782-83,1785-86$, and 1786-87 had high wheat prices (more than 18 rs./fa., referenced to the cost of living) in the studied period, whereas the only seasons with a rainfall pattern conducive to common bunt were $1786-87$ and $1787-88$. The $1786-87$ sea- 
son is a good candidate for being a year of higher common bunt outbreak, since the wheat price that year was high, and it belongs to the period 1783-87 in which reports of common bunt were frequent all over Spain. Information on wheat prices and prices index could not be found at Toledo in the studied time, but the years 1761, 1769, 1778-80, and 1783 recorded rain events that could cause common bunt outbreaks.

\section{FIGURE 2}

Wheat and barley prices (relative to cost of life), and rainfall bunt index in Seville in the period 1726-1800

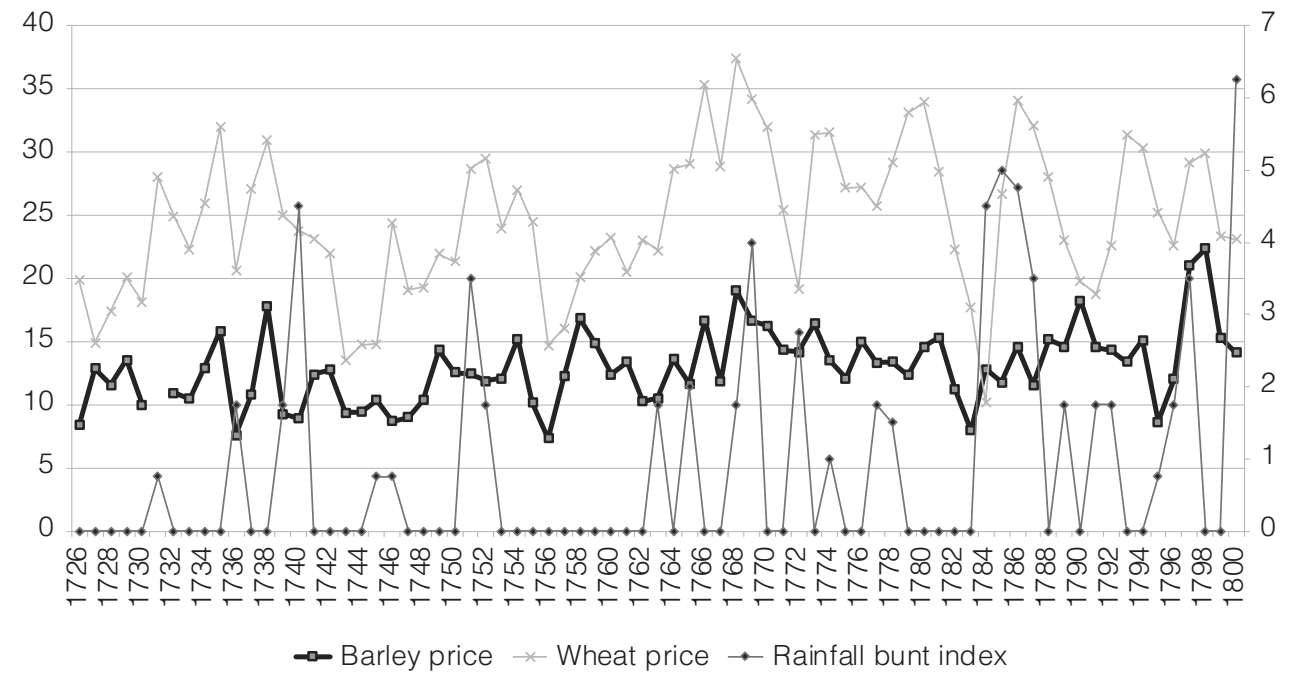

Note: wheat price (pts/hl) and barley price (rs./fa.) are referred to the Y-axis on the left, while rainfall bunt index is referred to the Y-axis on the right.

Source: data to make this figure were taken from Table 5.

\subsection{Common bunt management at the time}

The first report of 1755 recommended to plant wheat in elevated areas and not in low valleys, where mist may provoke the plague (Anonymous, 1755; Azcárate \& Maldonado, 1992: 313). Another anonymous report states that the cause of the bunt is contact with other grains or straw, and with the excessive heat and moisture of the sheaves. They propose to choose only clean grains to plant and to thresh on a clean threshing floor (Anonymous, 1765: 41).

The most generalized opinion was that common bunt was caused by mist (hence the synonym niebla or añublo). This explanation was accompanied by others, such as wet grains at harvest and/or at threshing time (Sainz, 1786), or grains that take a lot of soil 
and dirt at the threshing floor (Anonymous, 1790: 226). Benitez (1797) considered early harvesting and threshing to avoid possible rainfall and moisture on the grains and sieving the wheat grains (to remove dirt) and cover them with ash. Some other writers believed in the modern theories developed by the French botanist M. Tillet stating that the same black powder within the infected spikes was the cause of the plague (Azcárate \& Maldonado, 1992). In the $18^{\text {th }}$ and $19^{\text {th }}$ century, the application of a lime-ash water solution (lechada de cal or lexia de cal) ${ }^{2}$ to the seed was continuously reported as the most effective mean to control the plague (Sainz, 1786; Higueras, 1797; Palacios, 1798; Anonymous, 1799), although two reports doubted its efficacy (Benitez, 1797; Vallín, 1801) ${ }^{3}$. According to Vallín (1801:354) when refuting the Tillet theories, [...] it is difficult for me to see that an atom of dust that is buried with the grain at a certain depth, and that is washed by rains and snows of a whole winter, can influence the product of the grain to which it is stuck, mainly when the grain is not vitiated its internal organization, what is this subtle poison that can neither the water nor the earth extinguish? (...) Is it possible that it is so malignant that it waits for the germ to form, for the roots to take their full force, and for the grain to be formed, to devour it suddenly and circumvent our hopes? This did, in fact, describe the reality with some accuracy, but at that time the relationship between pathogen agent (cause) and plant plague (consequence) was not well understood (Agrios, 2005: 18).

Regarding production loss, a report of the time (mentioned above) reckons a one-seventh loss of wheat harvest (14.2\%) due to common bunt in Spain in 1790 (Lucas, 1790), which seems quite realistic, and fits with other reports at the end of the twentieth century in Turkey and Iran (Dubin \& Duveiller, 2011: 1163).

\subsection{The Enlightenment in Spain and the French connection}

It is interesting to note that common bunt outbreaks were also reported in France in the $18^{\text {th }}$ century, some of them a bit earlier. In 1739 most of the wheat in the Electorate of Chatellarault was destroyed by the common bunt. From 1730 to 1750, losses from common bunt in wheat were so frequent that French farmers appealed to the newspapers for in-

2. Sometimes ash (normally from the wood combustion) was replaced by lye, potash, urine, soot, or sea salt (AZCÁRATE \& MALDONADO, 1992; ANONYMOUS, 1797).

3. A few years earlier to the common bunt outbreaks in Spain, in 1755 French botanist M. Tillet, working with the common bunt, showed that he could increase the number of wheat plants developing the plague by dusting wheat kernels before planting with common bunt dust (the spores). He also could see the spores under the microscope but believed that is was a toxin from the common bunt dust, rather than the living spores and their infection process, that caused the plague. He also proposed the use of a lime-ash water solution in the seed to reduce the plagued wheat plants (TILLET, 1937). 
formation on the nature and control of this plague. In 1750 the prestigious fournal deVerdun was receiving many inquiries concerning common bunt (Zundel, 1953: 4-5). In 178487 there were again reports of common bunt attacks throughout France and they were so severe that threshers fell ill, some even died, because of breathing so many spores (Zadoks, 2008: 161). This problem prompted Tillet to do experimental work and in 1755 to write an essay explaining the cause of the common bunt, a seed-borne plague of infectious nature (Gaudet \& Menzies, 2012). Tillet demonstrated that the dark powder of the infected grains was the cause of the plague ${ }^{4}$. Coincidentally, that year corresponds to the first of many articles written in Spain. Therefore, the news from France influenced and promoted many of the articles in Spain, although most likely common bunt was affecting wheat in Spain earlier. Three of the reports consulted for this study were translations of French reports on the common bunt, and a fourth one is based on the results of an experiment performed in France. A 1791 letter by the "French citizen" Cadet de Vaux, from the Society of Agriculture of Paris, was translated and published in the Semanario de agricultura $y$ artes in 1797 (Vaux, 1797: 342). It clearly states that the cause of the common bunt is the same dark powder that grows instead of the kernel and proposes the use of clean seed and washing the seed in a lime-ash water solution. He also mentions common bunt outbreaks during 1784-87 and 1791 in different regions of France, which almost coincide with the period in which this plague struck with a greater severity in Spain, as described in this study (1783-87 and 1790). Likewise, a translation from French into Spanish of a report by the Society of Agriculture from the Department of the Seine from 1797 about how to apply a lime-ash water solution to the wheat seed was published in the Semanario de agricultura y artes (Anonymous, 1799). Alcalá Galiano (1786a: 4) published an article to explain the causes of common bunt and the means to prevent the plague following recent experiences made in view of the King of France in Rambouillet by Mr. Tessier [a researcher who repeated Tillet's experiments], a member of the Royal Academy of Sciences.

At this time, the Kingdom of Spain was governed by the House of Bourbon (Fernando VI, 1746-59; Carlos III, 1759-88; Carlos IV, 1788-1808), of French origin, which had recently replaced the House of Habsburg. The Kingdom of France was also governed by the same dynasty until the French Revolution. Physiocratic theories and Enlightenment thinking emphasized the importance of agriculture development to increase the wealth of a country. Both personal and national welfare somehow relied upon a good harvest and stable food supply to meet the needs of a growing population (another feature at this time

4. However, Tillet did not interpret his experiments properly and believed that the plague was caused by the poisonous substance the common bunt powder (the spores) produced, rather than by the infectious process carried out by the spores. These experiments influenced future researchers Prevost and Anton de Bary, who established plant pathology as a new science (AGRIOS, 2005: 18). 
in most Europe, including France and Spain) (Astigarraga, 2005). Plagues and pests were threats to the crops and therefore to human welfare, hence the necessity of establishing control measures. Spanish writers and reformists Campomanes and Jovellanos included agricultural essays in their work. P. R. de Campomanes was governor of the Council of Castille (Consejo de Castilla) for 30 years in the late $18^{\text {th }}$ century and developed an intense work regarding economic studies and implementation of reform programs under the reign of Carlos III. He was a prolific economic writer and promoted translations of European economists and reissued works of earlier Spanish economists ${ }^{5}$. M. G. de Jovellanos belonged to the Enlightenment and believed that both political and civil economy was an instrument for social reform, together with education and good governance (Llombart, 2006). These social reforms were accompanied by the publishing of an array of gazettes, letters, and miscellanea that began to appear in Spain in 1758, with the objective of spreading useful knowledge to large audiences (Memorias, Año literario, Memorial literario, El Correo mercantil, Semanario económico, etc.). Many of the articles in these materials dealt with agricultural issues (the new agriculture, crop pest management, the free market of grain, etc.) (Astigarraga, 2018) which had been of interest since the 1730s in the United Kingdom and the 1750s in France (Astigarraga, 2005). Some of the articles even related agricultural losses to bad weather, as in the Memorial literario (Alberola, 2015).

In addition, the agronomic works of the Frenchman Duhamel de Monceau and Rozier and the Irishman Henry Patullo (although settled in France) were translated into Spanish (Azcárate \& Maldonado, 1992). One of the books by H. L. Duhamel de Monceau (Eléments d'agriculture, written in 1762) was translated into Spanish by C. Gómez de Ortega in 1813. In this book, Duhamel de Monceau set up the principles of a "new agriculture" based on the methods of Jethro Tull (Cubero, 2018: 782). Patullo, in turn, was an agronomist and a physiocrat who also wrote on the "new agriculture". H. P. Dabout, an associate of Campomanes, translated his Essai sur l'amélioration des terres into Spanish in 1774 (Lluch \& Algemí, 1994). Other works accompanied these: the Dictionnaire universel d'agriculture, for instance, was written by J. B. F. Rozier and collaborators between 1781 and 1805. It was a great agricultural encyclopaedia that reached 12 volumes in 1805 (Cubero, 2018: 696-97) and was translated into Spanish by J. Álvarez Guerra between 1793 and 1803. All these translations were promoted by different Spanish societies of the time, and interestingly Duhamel de Monceau and Rozier mentioned the problem of the common bunt (Azcárate \& Maldonado, 1992).

5. He defended the free market of cereal at the national level and removing of the fees in his Tax Response (Respuesta Fiscal) of 1764, which gave way to the Royal Pragmatic (Real Pragmática) that Carlos III issued in 1765. This free market would promote the agriculture, through abundance and the good price of grains (LLOMBART, 2006). 
Thus, the flow of information from France at a time when the Enlightenment was set in Spain might have prompted the writing of the many reports about an important wheat plague shared in both countries.

\subsection{After the common bunt reports of the studied period}

The common bunt continued to be a threat to Spanish wheat in the $19^{\text {th }}$ century. There were written reports in 1845,1860 , and 1878 , but these were less frequent than in the previous century (Casas, 1845, 1860; Anonymous, 1878a, 1878b). The use of seed from bunt-free fields, the availability of more effective seed treatments (such as copper sulphate), and the use of machinery to apply those treatments gradually improved the situation, although as late as 1948 common bunt was still present in Spanish wheat fields (Benlloch, 1948). Del Moral reported that agricultural squads called cátedras ambulantes (traveling teachers) were created in 1923 to tour throughout Spain and explain how to mix copper sulphate, neutral copper acetate, or other fungicides with the wheat seed to get rid of the common bunt (Moral, 2014). Montes y Rodríguez (1986) reported that new fungicides (triadimenol+imazalil, metiltiophanate+maneb, etc.) used in Spain in the 1980s were highly effective at disinfecting wheat seed from common bunt.

Currently, the common bunt is under control in Spain, and outbreaks are no longer reported thanks to resistant varieties and especially seed treatments, but it is still a threat in developing countries (such as Syria, Iran, Iraq, and Afghanistan) where not all seed is treated (Wilcoxson \& Saari, 1996: 5-7).

\section{CONCLUSIONS}

The reports on common bunt in Spanish wheat between 1755-1801 coincided with a concentration of extreme rain events. This period coincided precisely with the Maldà Anomaly, a time of climatic irregularity (quick alternation of rainy periods with warm and dry periods) across the Western Mediterranean. In the articles of the time, the years 178387 and 1790 were described as having a high number of common bunt outbreaks, although the plague was present in Spain in every season. The evidence of a historical cause and effect relationship between weather and the plague is not conclusive, although from the Seville data the relationship between wheat price and the rainfall bunt index was positive and significant, and several years $(1763,1764,1768,1769,1777,1785,1786$, and 1792) had higher severity of common bunt at this location. The flow of information from France (where common bunt was also present) to Spain in the middle of the Enlighten- 
ment period and during the rise of physiocratic theories greatly influenced the creation of the many reports about common bunt in Spain. Information in other towns about common bunt outbreaks, their rainfall patterns, and annual wheat and barley prices, etc. may shed more light on the historical features of this plague in Spain.

\section{ACKNOWLEDGEMENTS}

This paper benefited greatly from the comments of Enrique Llopis and the continued support that Ana Isabel Queiroz gave to the first author. We also thank to the reviewers of Historia Agraria for their attentive review.

\section{REFERENCES}

Agencia Estatal de Meteorología (AEMET) (2019). http://www.aemet.es/es/ serviciosclimaticos/datosclimatologicos/valoresclimatologicos

Agrios, G. N. (2005). Plant Pathology. $5^{\text {th }}$ ed. Amsterdam: Elsevier-Academic Press.

Alberola, A. (2012). Plagas de langosta y clima en la España del siglo XVIII. Relaciones: Estudios de historia y sociedad, 33 (129), 21-50. http://www.scielo.org.mx/ scielo.php?script=sci_arttext\&pid=S0185-39292012000100002

Alberola, A. (2015). Tiempo, clima y enfermedad en la prensa española de la segunda mitad del siglo XVIII: Diarios meteorológicos y crónicas de desastres en el Memorial Literario. El Argonauta español (online). http://argonauta.revues.org/2142

Alberola, A., Balasch, C., Barriendoos, M., Cuadrat, J. M., Gil-Guirado, S., GrauSatorras, M., Mazón, J., Pérez Morales, A., Prohom, M., Pino, D., Saz, M. A., Tejedor, E. \& Tuset, J. (2018). Climatic Context and Meteorological Anomalies during 1783 in Eastern Iberian Peninsula: Atmospheric Processes and Impacts of a Singular "BadYear". Geophysical Research Abstracts, vol. 20. Wien: General Assembly, European Geosciences Union.

Alberola, A. \& Arrioja, L. A. (2020). Climatic Extremism and Crisis on the Iberian Peninsula and New Spain (1770-1800): Notes for a Comparative Study. In A. G. RoQUE, C. BRITo \& C.Veracini (Eds.), Peoples, Nature and Environments: Learning to Live Together (pp. 55-68). Cambridge: Cambridge Scholars Publishing. https://www.colmich.edu.mx/files/ceh/larrioja/publicaciones/pdf/2020_Climatic_extre mism_Iberian.pdf

AlCALÁ,V. (1786a). Preservativo seguro de la enfermedad del trigo llamada comúnmente niebla ó tizón. Actas y memorias de la Real Sociedad Económica de Amigos del País de 
la provincia de Segovia, 1-8. http://bibliotecadigital.jcyl.es/es/consulta/registro.cmd ?id $=4619$

AlcalÁ, V. (1786b). Sobre las enfermedades del trigo. Actas y memorias de la Real Sociedad Económica de Amigos del País de la provincia de Segovia, 334-58.

Allen, T.W., Jones, D. C., Boratynski, T. N.,Ykema, R. E. \& Rush, C. M. (2009). Application of the Humid Thermal Index for Relating Bunted Kernel Incidence to Soilborne Tilletia indica Teliospores in an Arizona durum wheat field. Plant Disease, 93 (7), 713-19.

AnONymous (1755). Tratado de agricultura. Discursos mercuriales, (1), 17 nov., 1-24.

Anonymous (1765). Tizón del trigo. Semanario económico, (1), 41-2.

Anonymous (1790). Nuevas pruebas de que el tizón del trigo es contagioso. Memorial literario, 222-26.

AnONYmous (1797). Agricultura. Semanario de agricultura y artes dirigido a los párro$\cos , 149-52$.

ANONYMous (1799). Instrucción sobre el modo de preservar al trigo del tizón, por la Sociedad de Agricultura del Departamento del Sena. Semanario de agricultura y artes dirigido a los párrocos, t. 6 (148), 273-82. https://www.mapa.gob.es/ministerio/ pags/Biblioteca/Revistas/pdf_SAP/SP_1799_06_148_273288.pdf

Anonymous (1878a). Carta sobre el tizón desde Barquilla (Salamanca). Gaceta Agrícola del Ministerio de Fomento, t. IX, 201.

Anonymous (1878b). Carta sobre el tizón desde Esquivias (Toledo). Gaceta Agrícola del Ministerio de Fomento, t. Ix, 467.

Astigarraga, J. (2005). La Fisiocracia en España: Los Principes de la législation universelle (1776) de G. L. Schmid d'Avenstein. Historia Agraria, (37), 545-71. http://www.historiaagraria.com/FILE/articulos/jesusastigarraga37.pdf

Astigarraga, J. (2018). Prensa económica de la Ilustración española (1758-1792). Studia historica. Historia moderna, 40 (2), 199-231.

AzCÁRATE, I. (1997). Plagas agrícolas y forestales en España en los siglos XVIII y XIX. Madrid: Ministerio de Agricultura, Pesca y Alimentación. https://www.mapa.gob.es/ministerio/pags/biblioteca/fondo/pdf/14985_all.pdf

AzCÁRATE, I. \& MALDONADO, L. (1992). La plaga de la langosta y el tizón del trigo en la España ilustrada. Llull, 15 (29), 309-30. https:/dialnet.unirioja.es/servlet/articulo? codigo $=62109$

BARriendos, M. (1997). Climatic Variations in the Iberian Peninsula during the Late Maunder Minimum (AD 1675-1715): An Analysis of Data from Rogation Ceremonies. The Holocene, 7 (1), 105-11.

BARRIENDOS, M. \& GómeZ, L. (1997). Análisis de la incidencia de la actividad volcánica en las temperaturas medias mensuales de Barcelona (ss. XVIII-XX). In J. MARTíN VIDE (Ed.), Avances en climatología histórica en España (pp. 71-90). Barcelona: Oikos-Tau. 
Barriendos, M. \& Llasat, M. C. (2003). The Case of the 'Maldá' Anomaly in the Western Mediterranean Basin (AD 1760-1800): An Example of a Strong Climatic Variability. Climatic Change, 61 (1), 191-216.

BARRIENDOS, M. \& MARTín VIDE, J. (1998). Secular Climatic Oscillations as Indicated by Catastrophic Floods in the Spanish Mediterranean Coastal Area (14th-19th Centuries). Climatic Change, (38), 473-91.

Barriendos, M., Ruiz Bellet, J. L., Tuset, J., Mazón, J., Balasch, J. C., Pino, D. \& Ayala, J. L. (2014). The 'Prediflood' Database of Historical Floods in Catalonia (NE Iberian Peninsula) AD 1035-2013, and its Potential Applications in Flood Analysis. Hydrology and Earth System Sciences, (18), 4807-23.

BENíTez, F. (1797). Extracto de una carta del Doctor Don Fernando Benitez, cura párroco en Hardales, Arzobispado de Sevilla. Semanario de agricultura y artes dirigido a los párrocos, t. 2, (29), 35-6.

Benlloch, M. (1948). El "tizon" del trigo. Hojas divulgadoras, (19-48 H). https://www.mapa.gob.es/ministerio/pags/biblioteca/hojas/hd_1948_19.pdf

CASAs, N. (1845). Tizón y carbón de los granos: Modo de evitarlos. El Amigo del País, t. II, 265, 291.

Casas, N. (1860). Tizón del trigo. Agricultura Española, t. III, 219.

Clavero, J. (1797). Notas (after: Carta del ciudadano Cadet de Vaux, de la Sociedad de Agricultura de París a los redactores de un periódico de agricultura). Semanario de agricultura y artes dirigido a los párrocos, (2), 345-47.

Chester, K. S. (1946). The Nature and Prevention of the Cereal Rusts and Exemplified in the Leaf Rust of Wheat. Waltham: Chronica Botanica Company.

Cremades, C. (2017). Rogativas pro pluvia y pro serenitate en la cuenca del Segura durante la PEH: información suministrada por el archivo diocesano de Orihuela. In A. Alberola (Ed.), Riesgo, desastre y miedo en la península Ibérica y México durante la Edad Moderna (pp. 47-69). Alicante/Michoacán: Universidad de Alicante/El Colegio de Michoacán.

Cubero, J. I. (2018). Historia general de la agricultura. Córdoba: Guadalmazán.

Domínguez Castro, F., Ribera, P., García Herrera, R., Vaquero, J. M., Barriendos, M., Cuadrat, J. M. \& Moreno, J. M. (2012). Assessing Extreme Droughts in the Iberian Peninsula during 1750-1850 from Rogation Ceremonies. Climate of the Past, 8 (2), 705-22.

Dubin, H. J. \& DuveILLER, E. (2011). Fungal, Bacterial and Nematode Diseases of Wheat: Breeding for Resistance and Other Control Measures. In A. P. BonJEAN, W. J. ANGus \& M van Ginkel (Eds.), The World Wheat Book 2: A History of Wheat Breeding. (pp. 1131-91). Paris: Tec \& Doc. 
Gaudet, D. \& Menzies, J. (2012). Common Bunt of Wheat: An Old Foe remains a Current Threat. In I. SHARMA (Ed.), Disease Resistance in Wheat (pp. 220-35). Cambridge: Cabi. (Plant Protection Series, 1).

García Torres, A. (2015). Plagas de langosta en la segunda mitad del siglo XVIII en el sur alicantino. Revista de Historia Moderna. Anales de la Universidad de Alicante, (33). 287-308. https://rua.ua.es/dspace/bitstream/10045/52708/1/Revista-Historia-Moderna _33_14.pdf

GARCÍA ToRrES, A. (2017). Extremismo climático y peligro biológico en el sureste español (1780-1800). Revista de Historia Moderna. Anales de la Universidad de Alicante, (35), 345-76.

Higueras, P. (1797). Método de separar y limpiar el tizón, por Pascual Higueras, visitador de montes y plantíos. Memorias de la Real Sociedad de Amigos del País de Madrid, (1), 207.

KisLev, M. E. (1982). Stem Rust of Wheat 3300 Years Old Found in Israel. Science, (216), 993-94.

Kottek, M., Grieser, J., Beck, C., Rudolf, B. \& Rubel, F. (2006). World Map of the Köppen-Geiger Climate Classification Updated. Meteorologische Zeitschrift, 15 (3), 259-63.

LuCAs (1790). Cálculo de los perjuicios que causa el tizon de trigo en España. Memorial literario, 274-82.

LUCAS (1794). Respuesta del autor de la historia del tizón á la carta segunda de D. Eustaquio del Valle y Ximenez. Memorial literario, 383-403.

LLOMBART, V. A. (2006). Economía política y reforma en la Europa mediterránea del siglo xviII: Una perspectiva española. Mediterráneo económico, (9), 95-113.

LLopis, E. \& JeREZ, M. (2001). El mercado de trigo en Castilla y León, 1691-1788: Arbitraje espacial e intervención, 1691-1788. Historia Agraria, (25), 13-68.

LLOPIS, E. \& SoTOCA, S. (2005). Antes, bastante antes: La primera fase de la integración del mercado español de trigo, 1725-1808. Historia Agraria, (36), 225-62. http://historiaagraria.com/FILE/articulos/ha36_llopis-sotoca.pdf

Llopis, E., García Hiernaux, A., García, H., González, M. \& Hernández, R. (2009). Índices de precios de tres ciudades españolas, 1680-1800: Palencia, Madrid y Sevilla. América Latina en la historia económica, (32), 31-80. http://www.scielo.org.mx/scielo.php?script=sci_arttext\&pid=S140522532009000200004

Llopis, E., Sebastián, J. A., Bernardos, J. U.,Velasco, A. L. \& Abarca, V. (2018). ¿Descendió el producto agrario por habitante en la Europa moderna?: El caso castellano. Investigaciones de Historia Económica, 14 (2), 69-81.

Lluch, E. \& Argemí, L. (1994). Physiocracy in Spain. History of Political Economy, 26 (4), 613-27. http://diposit.ub.edu/dspace/bitstream/2445/9172/1/137068.pdf 
MARTín Vide, J. \& BARRIEndos, M. (1995). The Use of Rogation Ceremony Records in Climatic Reconstruction: A Case Study from Catalonia (Spain). Climatic Change, (30), 201-21.

Martínez Moreno, F. \& Solís, I. (2019). Wheat Rust Evolution in Spain: An Historical Review. Phytopathologia Mediterranea, 58 (1), 3-16.

Montes, F. DE P. \& RodrígueZ, A. (1986). Tratamientos fungicidas de las semillas de trigo: Control del carbón desnudo (Ustilago tritici Pers.) y del tizón (Tilletia foetida Wall.). Boletín de Sanidad Vegetal. Plagas, 12 (1), 115-20.

MORAL, J. DEL (2014). La sanidad vegetal en España, visión histórica. Master Conference. Sevilla: Universidad de Sevilla.

MuÑoz, J. (2019). Riesgo y catástrofe: El impacto de las plagas de langosta en la España de finales del siglo XVIII (1770-1800). PhD thesis. Alicante: Universidad de Alicante. https://rua.ua.es/dspace/bitstream/10045/90648/1/tesis_jesus_munoz_pertierra.pdf

Oliva, M., Ruiz Fernández, J., Barriendos, M., Benito G., Cuadrat J. M. et al. (2018). The Little Ice Age in Iberian mountains. Earth-Science Reviews, (177), 175-208.

Palacios, E. (1798). Carta de Eugenio Palacios Olave sobre el tizón. Semanario de agricultura y artes dirigido a los párrocos, t. 4, 175-76.

Ponsot, P. (1986). Atlas de historia económica de la Baja Andalucía. Sevilla: Editoriales Andaluzas Unidas.

Rivero, J. (2013). Los cambios técnicos del cultivo de cereal en España (1800-1930). Madrid: Ministerio de Agricultura, Alimentación y Medio Ambiente.

RodRIGO, F. S. \& BARRIENDOS, M. (2008). Reconstruction of Seasonal and Annual Rainfall Variability in the Iberian Peninsula $\left(16^{\text {th }}-20^{\text {th }}\right.$ centuries $)$ from documentary data. Global and Planetary Changes, 63 (2-3), 243-57.

Royo, C. \& Briceño-Felix, G. A. (2011). Wheat Breeding in Spain. In A. P. Bonjean, W. J. ANGus \& M. van Ginkel (Eds.), The World Wheat Book 2: A History of Wheat Breeding (pp. 121-54). Paris: Tec \& Doc.

SAINZ, P. (1786). Sobre el tizón del trigo. Actas y memorias de la Real Sociedad Económica de Amigos del País de la provincia de Segovia, t. II, 326-33.

SMILEY, R.W. (1997). Risk Assessment for Karnal Bunt Occurrence in the Pacific Northwest. Plant Disease, 81 (6), 689-92.

Tejedor, E., SAZ, M. A., CuAdrat, J. M., EsPer, J. \& Luis, M. DE (2017). Temperature Variability in the Iberian Range since 1602 Inferred from Tree-Ring Records. Climate of the Past, (13), 93-105.

Tejedor, E., Luis, M. De, Barriendos, M., Cuadrat, J. M., Luterbacher, J. \& Saz, M. A. (2019). Rogation Ceremonies: A Key to Understanding Past Drought Variability in Northeastern Spain since 1650. Climate of the Past, 15 (5), 1647-64. 
Tillet, M. (1937 [1755]). Dissertation on the Cause of the Corruption and Smutting of the Kernels of Wheat in the Head, and on the Means of Preventing these Untoward Circumstances. Ithaca: American Phytopathological Society. (Phytopathology Classics, 5).

VALle, E. DEL (1790). Carta de Eustaquio del Valle sobre la causa productora del tizón. Memorial literario, 1789-90.

VALLín. (1801). Del tizón del trigo. Semanario de agricultura y artes dirigido a los párrocos, t. X, (257), 353-59. https://www.miteco.gob.es/ministerio/pags/Biblioteca/Revistas/ pdf_SAP\%2FSP_1801_10_257_353368.pdf.

VAUX, C. DE (1797). Carta del ciudadano Cadet de Vaux, de la Sociedad de Agricultura de París a los redactores de un periódico de agricultura. Semanario de agricultura y artes dirigido a los párrocos, t. 2, (49), 341-45. https://www.miteco.gob.es/ ministerio/pags/Biblioteca/Revistas/pdf_SAP\%2FSP_1797_02_049_341348.pdf

Wilcoxson, R. D. \& SAARI, E. E. (Eds.) (1996). Bunt and Smut Diseases of Wheat: Concepts and Methods of Disease Management. Mexico, DF: Centro Internacional de Mejoramiento de Maíz y Trigo.

Workneh, F., Allen, T. W., Nash, G. H., Narasimhan, B., Srinivasan, R. \& Rush, C. M. (2008). Rainfall and Temperature Distinguish between Karnal Bunt Positive and Negative Years in Wheat Fields in Texas. Phytopathology, (98), 95-100.

Zadoks, J. C. (2008). On the Political Economy of Plant Disease Epidemics. Wageningen: Wageningen Academic Publishers.

Zadoks, J. C. (2013). Crop Protection in Medieval Agriculture. Leiden: Sidestone Press. ZundeL, G. L. (1953). The Ustilaginales of the World. Pennsylvania: State College. 


\section{APPENDIX}

TABLE 5

Wheat prices index and bunt index in Seville, 1726-1801

\begin{tabular}{|c|c|c|c|c|c|c|c|}
\hline Yeara $^{a}$ & $\begin{array}{l}\text { Wheat price } \\
(\mathrm{pts} / \mathrm{hl})^{\mathrm{b}}\end{array}$ & $\begin{array}{l}\text { Wheat price referred } \\
\text { to cost of living }\end{array}$ & $\begin{array}{c}\text { Barley price } \\
\text { (rs./fa.) }\end{array}$ & $\begin{array}{l}\text { Barley price referred } \\
\text { to cost of living }\end{array}$ & $\begin{array}{c}\text { Wheat/barley } \\
\text { price ratio }\end{array}$ & $\begin{array}{l}\text { References } \\
\text { bunt index }\end{array}$ & $\begin{array}{c}\text { Rainfall } \\
\text { bunt index }\end{array}$ \\
\hline 1726 & 7.50 & 19.87 & 7.0 & 8.4 & 2.4 & 0 & 0 \\
\hline 1727 & 6.00 & 14.90 & 11.5 & 12.9 & 1.2 & 0 & 0 \\
\hline 1728 & 7.21 & 17.39 & 10.7 & 11.6 & 1.5 & 0 & 0 \\
\hline 1729 & 8.44 & 20.04 & 12.7 & 13.5 & 1.5 & 0 & 0 \\
\hline 1730 & 7.77 & 18.15 & 9.5 & 10.0 & 1.8 & 0 & 0 \\
\hline 1731 & 13.74 & 27.98 & - & - & - & 0 & 0.75 \\
\hline 1732 & 11.82 & 24.94 & 11.5 & 10.9 & 2.3 & 0 & 0 \\
\hline 1733 & 10.59 & 22.34 & 11.0 & 10.5 & 2.1 & 0 & 0 \\
\hline 1734 & 13.36 & 25.94 & 14.8 & 12.9 & 2.0 & 0 & 0 \\
\hline 1735 & 16.81 & 31.95 & 18.5 & 15.8 & 2.0 & 0 & 0 \\
\hline 1736 & 9.79 & 20.65 & 8.0 & 7.6 & 2.7 & 0 & 1.75 \\
\hline 1737 & 13.85 & 27.06 & 12.3 & 10.9 & 2.5 & 0 & 0 \\
\hline 1738 & 15.09 & 30.90 & 19.3 & 17.8 & 1.7 & 0 & 0 \\
\hline 1739 & 12.16 & 24.98 & 10.0 & 9.3 & 2.7 & 0 & 1.75 \\
\hline 1740 & 11.71 & 23.77 & 9.8 & 8.9 & 2.7 & 0 & 4.5 \\
\hline 1741 & 11.14 & 23.14 & 13.3 & 12.4 & 1.9 & 0 & 0 \\
\hline 1742 & 9.34 & 22.02 & 12.0 & 12.7 & 1.7 & 0 & 0 \\
\hline 1743 & 5.41 & 13.48 & 8.3 & 9.4 & 1.4 & 0 & 0 \\
\hline 1744 & 6.00 & 14.77 & 8.5 & 9.4 & 1.6 & 0 & 0 \\
\hline 1745 & 6.41 & 14.79 & 10.0 & 10.4 & 1.4 & 0 & 0.75 \\
\hline 1746 & 11.04 & 24.40 & 8.8 & 8.7 & 2.8 & 0 & 0.75 \\
\hline 1747 & 8.11 & 19.07 & 8.5 & 9.0 & 2.1 & 0 & 0 \\
\hline 1748 & 8.78 & 19.27 & 10.5 & 10.4 & 1.9 & 0 & 0 \\
\hline 1749 & 10.20 & 21.97 & 14.8 & 14.3 & 1.5 & 0 & 0 \\
\hline 1750 & 12.05 & 21.32 & 15.8 & 12.6 & 1.7 & 0 & 0 \\
\hline 1751 & 17.68 & 28.71 & 17.0 & 12.4 & 2.3 & 0 & 3.5 \\
\hline 1752 & 16.22 & 29.51 & 14.5 & 11.9 & 2.5 & 0 & 1.75 \\
\hline 1753 & 14.30 & 23.99 & 16.0 & 12.1 & 2.0 & 0 & 0 \\
\hline 1754 & 16.55 & 27.01 & 20.7 & 15.2 & 1.8 & 0 & 0 \\
\hline 1755 & 12.72 & 24.43 & 11.8 & 10.2 & 2.4 & 0.5 & 0 \\
\hline 1756 & 6.90 & 14.67 & 7.7 & 7.3 & 2.0 & 0.5 & 0 \\
\hline 1757 & 7.99 & 16.07 & 13.5 & 12.2 & 1.3 & 0.5 & 0 \\
\hline 1758 & 10.36 & 20.05 & 19.3 & 16.9 & 1.2 & 0.5 & 1.5 \\
\hline 1759 & 11.94 & 22.18 & 17.8 & 14.9 & 1.5 & 0.5 & 0 \\
\hline 1760 & 12.95 & 23.27 & 15.3 & 12.4 & 1.9 & 0.5 & 0 \\
\hline 1761 & 11.26 & 20.51 & 16.3 & 13.4 & 1.5 & 0.5 & 0 \\
\hline 1762 & 13.66 & 23.06 & 13.5 & 10.3 & 2.2 & 0.5 & 0 \\
\hline 1763 & 14.26 & 22.19 & 15.0 & 10.5 & 2.1 & 0.5 & 1.75 \\
\hline 1764 & 17.34 & 28.67 & 18.3 & 13.6 & 2.1 & 0.5 & 0 \\
\hline 1765 & 18.24 & 29.03 & 16.3 & 11.6 & 2.5 & 0.5 & 2 \\
\hline 1766 & 21.96 & 35.35 & 23.0 & 16.7 & 2.1 & 0.5 & 0 \\
\hline 1767 & 18.47 & 28.91 & 16.8 & 11.8 & 2.4 & 0.5 & 0 \\
\hline
\end{tabular}




\begin{tabular}{|c|c|c|c|c|c|c|c|}
\hline Year $^{\mathrm{a}}$ & $\begin{array}{l}\text { Wheat price } \\
(\mathrm{pts} / \mathrm{hl})^{\mathrm{b}}\end{array}$ & $\begin{array}{l}\text { Wheat price referred } \\
\text { to cost of living }\end{array}$ & $\begin{array}{c}\text { Barley price } \\
\text { (rs./fa.) }\end{array}$ & $\begin{array}{l}\text { Barley price referred } \\
\text { to cost of living }\end{array}$ & $\begin{array}{l}\text { Wheat/barley } \\
\text { price ratio }\end{array}$ & $\begin{array}{l}\text { References } \\
\text { bunt index }\end{array}$ & $\begin{array}{c}\text { Rainfall } \\
\text { bunt index }\end{array}$ \\
\hline 1768 & 24.32 & 37.40 & 27.5 & 19.0 & 2.0 & 0.5 & 1.75 \\
\hline 1769 & 23.65 & 34.20 & 25.5 & 16.6 & 2.1 & 0.5 & 4 \\
\hline 1770 & 20.61 & 31.99 & 23.3 & 16.3 & 2.0 & 1 & 0 \\
\hline 1771 & 15.99 & 25.47 & 20.0 & 14.3 & 1.8 & 0.5 & 0 \\
\hline 1772 & 12.05 & 19.16 & 19.8 & 14.1 & 1.4 & 0.5 & 2.75 \\
\hline 1773 & 20.27 & 31.40 & 23.5 & 16.4 & 1.9 & 0.5 & 0 \\
\hline 1774 & 21.40 & 31.56 & 20.3 & 13.5 & 2.3 & 0.5 & 1 \\
\hline 1775 & 18.02 & 27.19 & 17.8 & 12.1 & 2.3 & 0.5 & 0 \\
\hline 1776 & 17.57 & 27.22 & 21.5 & 15.0 & 1.8 & 0.5 & 0 \\
\hline 1777 & 17.34 & 25.72 & 20.0 & 13.4 & 1.9 & 0.5 & 1.75 \\
\hline 1778 & 20.27 & 29.15 & 20.7 & 13.4 & 2.2 & 0.5 & 1.5 \\
\hline 1779 & 23.85 & 33.11 & 19.8 & 12.4 & 2.7 & 0.5 & 0 \\
\hline 1780 & 27.29 & 33.94 & 26.0 & 14.6 & 2.3 & 0.5 & 0 \\
\hline 1781 & 21.98 & 28.47 & 26.3 & 15.3 & 1.9 & 1 & 0 \\
\hline 1782 & 15.88 & 22.34 & 17.7 & 11.2 & 2.0 & 1 & 0 \\
\hline 1783 & 11.71 & 17.65 & 11.8 & 8.0 & 2.2 & 1.5 & 0 \\
\hline 1784 & 7.66 & 10.14 & 21.5 & 12.8 & 0.8 & 1.5 & 4.5 \\
\hline 1785 & 22.97 & 26.65 & 22.5 & 11.8 & 2.3 & 1.5 & 5 \\
\hline 1786 & 31.53 & 34.10 & 30.0 & 14.6 & 2.3 & 1.5 & 4.75 \\
\hline 1787 & 28.15 & 32.08 & 22.5 & 11.6 & 2.8 & 1.5 & 3.5 \\
\hline 1788 & 21.63 & 28.01 & 26.0 & 15.2 & 1.8 & 1 & 0 \\
\hline 1789 & 18.92 & 23.00 & 26.7 & 14.6 & 1.6 & 1 & 1.75 \\
\hline 1790 & 14.64 & 19.77 & 30.0 & 18.2 & 1.1 & 1.5 & 0 \\
\hline 1791 & 13.81 & 18.74 & 23.8 & 14.5 & 1.3 & 1 & 1.75 \\
\hline 1792 & 18.47 & 22.63 & 26.0 & 14.3 & 1.6 & 1 & 1.75 \\
\hline 1793 & 30.25 & 31.39 & 28.7 & 13.4 & 2.3 & 1 & 0 \\
\hline 1794 & 29.84 & 30.35 & 33.0 & 15.1 & 2.0 & 1 & 0 \\
\hline 1795 & 22.07 & 25.24 & 16.8 & 8.6 & 2.9 & 1 & 0.75 \\
\hline 1796 & 20.95 & 22.64 & 24.8 & 12.0 & 1.9 & 1 & 1.75 \\
\hline 1797 & 29.26 & 29.13 & 47.0 & 21.1 & 1.4 & 1 & 3.5 \\
\hline 1798 & 32.56 & 29.94 & 54.0 & 22.4 & 1.3 & 1 & 0 \\
\hline 1799 & 22.48 & 23.34 & 32.8 & 15.3 & 1.5 & 1 & 0 \\
\hline 1800 & 24.77 & 23.07 & 33.7 & 14.1 & 1.6 & 0.5 & 6.25 \\
\hline 1801 & 33.78 & 26.82 & - & - & - & 0.5 & 0 \\
\hline
\end{tabular}

${ }^{a}$ The year indicates the season in which the wheat was harvested (e.g. year 1785 corresponds to season 1784$85)$.

${ }^{\mathrm{b}}$ Wheat prices were taken in January and refer to wheat production of the previous season. Prices referenced to cost of living in Seville. Dates and figures in bold print point out years with a high wheat price.

${ }^{\mathrm{c}}$ References bunt index (national): out of the period 1755-1801 (0); within the period of references to common bunt (1755-1801) (0.5); references to bunt outbreak years (1770, 1781-99) (1); references to more specific bunt outbreak years $(1783-87,1790)(1.5)$.

${ }^{d}$ Rainfall bunt index (from the excessive rain events between November and May): catastrophic flooding (value 0.5); extraordinary flooding with disturbing but not destructive river overflows (0.75); pro serenitate rogations or river floods with periods of persistent rains (1), extreme rain events from November, December, and January received a value +1 .

Sources: Ponsot (1986: 520-21); Llopis et al. (2009); data to calculate the rainfall bunt index were taken from Table 3. 
TABLE 6

Wheat prices index and bunt index in Murcia, 1762-1800

\begin{tabular}{|c|c|c|c|c|}
\hline Year $^{\mathrm{a}}$ & Wheat price (rs./fa.) $)^{\mathrm{b}}$ & Wheat price referred to cost of living ${ }^{\mathrm{b}}$ & References bunt index ${ }^{c}$ & Rainfall bunt index ${ }^{d}$ \\
\hline 1762 & 31.53 & 23.98 & 0.5 & 0 \\
\hline 1763 & 36.66 & 25.71 & 0.5 & 3 \\
\hline 1764 & 37.35 & 27.81 & 0.5 & 0 \\
\hline 1765 & 39.18 & 28.09 & 0.5 & 0 \\
\hline 1766 & 50.70 & 36.77 & 0.5 & 0 \\
\hline 1767 & 38.72 & 27.31 & 0.5 & 0 \\
\hline 1768 & 45.57 & 31.56 & 0.5 & 2 \\
\hline 1769 & 47.63 & 31.03 & 0.5 & 0 \\
\hline 1770 & 46.00 & 32.17 & 1 & 0 \\
\hline 1771 & 33.67 & 24.15 & 0.5 & 0 \\
\hline 1772 & 36.29 & 26.00 & 0.5 & 0 \\
\hline 1773 & 52.62 & 36.72 & 0.5 & 0 \\
\hline 1774 & 53.39 & 35.48 & 0.5 & 0 \\
\hline 1775 & 47.34 & 32.18 & 0.5 & 0.75 \\
\hline 1776 & 43.57 & 30.41 & 0.5 & 1 \\
\hline 1777 & 39.70 & 26.52 & 0.5 & 2 \\
\hline 1778 & 38.50 & 24.94 & 0.5 & 3 \\
\hline 1779 & 39.98 & 25.01 & 0.5 & 0 \\
\hline 1780 & 58.70 & 32.89 & 0.5 & 0 \\
\hline 1781 & 66.67 & 38.90 & 1 & 0 \\
\hline 1782 & 39.21 & 24.85 & 1 & 0 \\
\hline 1783 & 39.20 & 26.61 & 1.5 & 0 \\
\hline 1784 & 34.86 & 20.79 & 1.5 & 4 \\
\hline 1785 & 48.55 & 25.37 & 1.5 & 0 \\
\hline 1786 & 54.44 & 26.52 & 1.5 & 0 \\
\hline 1787 & 43.29 & 22.22 & 1.5 & 0 \\
\hline 1788 & 48.70 & 28.41 & 1 & 0 \\
\hline 1789 & 61.10 & 33.46 & 1 & 0 \\
\hline 1790 & 56.17 & 34.16 & 1.5 & 1 \\
\hline 1791 & 48.32 & 29.53 & 1 & 0 \\
\hline 1792 & 53.84 & 29.71 & 1 & 0 \\
\hline 1793 & 57.71 & 26.98 & 1 & 0 \\
\hline 1794 & 74.66 & 34.20 & 1 & 2 \\
\hline 1795 & 63.41 & 32.67 & 1 & 0 \\
\hline 1796 & 60.02 & 29.22 & 1 & 0 \\
\hline 1797 & 72.00 & 32.29 & 1 & 3 \\
\hline 1798 & 59.36 & 24.59 & 1 & 0 \\
\hline 1799 & 63.46 & 29.68 & 1 & 0 \\
\hline 1800 & 67.93 & 28.50 & 0.5 & 0 \\
\hline
\end{tabular}

${ }^{a}$ The year indicates the season in which the wheat was harvested (e.g. year 1785 corresponds to season 1784$85)$.

${ }^{\mathrm{b}}$ Wheat prices were taken in January and refer to wheat production of the previous season. Prices referenced to cost of living in Seville. Dates and figures in bold print point out years with a high wheat price.

${ }^{\mathrm{c}}$ References bunt index (national): out of the period 1755-1801 (0); within the period of references to common bunt (1755-1801) (0.5); references to bunt outbreak years (1770, 1781-99) (1); references to more specific bunt outbreak years $(1783-87,1790)(1.5)$.

${ }^{\mathrm{d}}$ Rainfall bunt index (from the excessive rain events between November and May): catastrophic flooding (value 0.5 ); extraordinary flooding with disturbing but not destructive river overflows (0.75); pro serenitate rogations or river floods with periods of persistent rains (1); extreme rain events from November, December, and January received a value +1 .

Sources: Llopis and Sotoca (2005); Llopis et al. (2009); data to calculate the rainfall bunt index were taken from Table 3. 
TABLE 7

Wheat prices index and bunt index in Zamora, 1726-88

\begin{tabular}{|c|c|c|c|c|}
\hline$\overline{\text { Year }^{\mathrm{a}}}$ & Wheat price (rs./fa. $)^{b}$ & Wheat price referred to cost of living & References bunt index ${ }^{c}$ & Rainfall bunt index $x^{\mathrm{d}}$ \\
\hline 1726 & 8.00 & 9.33 & 0 & 0 \\
\hline 1727 & 9.50 & 9.34 & 0 & 0 \\
\hline 1728 & 9.00 & 9.75 & 0 & 0 \\
\hline 1729 & 13.50 & 13.30 & 0 & 2 \\
\hline 1730 & 12.00 & 12.38 & 0 & 0 \\
\hline 1731 & 11.00 & 11.66 & 0 & 0 \\
\hline 1732 & 10.50 & 12.03 & 0 & 0 \\
\hline 1733 & 15.75 & 13.61 & 0 & 0 \\
\hline 1734 & 27.50 & 18.82 & 0 & 0 \\
\hline 1735 & 15.00 & 16.03 & 0 & 0 \\
\hline 1736 & 10.00 & 10.64 & 0 & 0 \\
\hline 1737 & 27.00 & 25.69 & 0 & 0 \\
\hline 1738 & 20.00 & 19.01 & 0 & 0 \\
\hline 1739 & 18.00 & 17.46 & 0 & 0 \\
\hline 1740 & 18.00 & 16.48 & 0 & 1.5 \\
\hline 1741 & 27.00 & 24.82 & 0 & 0 \\
\hline 1742 & 20.00 & 20.20 & 0 & 0 \\
\hline 1743 & 11.00 & 11.04 & 0 & 0 \\
\hline 1744 & 7.00 & 8.24 & 0 & 0 \\
\hline 1745 & 11.00 & 13.98 & 0 & 0 \\
\hline 1746 & 10.00 & 11.88 & 0 & 0 \\
\hline 1747 & 12.00 & 12.96 & 0 & 0 \\
\hline 1748 & 20.00 & 18.87 & 0 & 0 \\
\hline 1749 & 21.00 & 16.95 & 0 & 0 \\
\hline 1750 & 20.00 & 16.09 & 0 & 0 \\
\hline 1751 & 19.00 & 14.73 & 0 & 0 \\
\hline 1752 & 20.00 & 14.28 & 0 & 0 \\
\hline 1753 & 18.00 & 11.29 & 0 & 0 \\
\hline 1754 & 28.00 & 16.54 & 0 & 0 \\
\hline 1755 & 27.00 & 17.09 & 0.5 & 0 \\
\hline 1756 & 10.00 & 8.16 & 0.5 & 0 \\
\hline 1757 & 10.00 & 8.75 & 0.5 & 0 \\
\hline 1758 & 12.00 & 10.53 & 0.5 & 0 \\
\hline 1759 & 13.00 & 11.67 & 0.5 & 0 \\
\hline 1760 & 18.00 & 13.39 & 0.5 & 0 \\
\hline 1761 & 21.50 & 15.73 & 0.5 & 0 \\
\hline 1762 & 28.00 & 19.53 & 0.5 & 0 \\
\hline 1763 & 27.00 & 18.89 & 0.5 & 0 \\
\hline 1764 & 28.00 & 16.90 & 0.5 & 0 \\
\hline 1765 & 29.00 & 16.93 & 0.5 & 0 \\
\hline
\end{tabular}




\begin{tabular}{|c|c|c|c|c|}
\hline Year $^{\mathrm{a}}$ & Wheat price (rs./fa.) ${ }^{b}$ & Wheat price referred to cost of living ${ }^{b}$ & References bunt index ${ }^{c}$ & Rainfall bunt index \\
\hline 1766 & 29.00 & 17.23 & 0.5 & 0 \\
\hline 1767 & 20.50 & 12.07 & 0.5 & 0 \\
\hline 1768 & 30.00 & 18.58 & 0.5 & 0 \\
\hline 1769 & 31.00 & 15.64 & 0.5 & 0 \\
\hline 1770 & 35.00 & 20.42 & 1 & 0 \\
\hline 1771 & 25.00 & 12.72 & 0.5 & 0 \\
\hline 1772 & 25.00 & 13.70 & 0.5 & 0 \\
\hline 1773 & 27.00 & 15.99 & 0.5 & 0 \\
\hline 1774 & 29.00 & 17.63 & 0.5 & 0 \\
\hline 1775 & 25.00 & 15.81 & 0.5 & 0 \\
\hline 1776 & 22.50 & 14.04 & 0.5 & 0 \\
\hline 1777 & 28.00 & 17.94 & 0.5 & 0 \\
\hline 1778 & 22.00 & 13.06 & 0.5 & 0 \\
\hline 1779 & 35.00 & 22.57 & 0.5 & 0 \\
\hline 1780 & 35.00 & 22.08 & 0.5 & 0 \\
\hline 1781 & 31.00 & 19.90 & 1 & 0 \\
\hline 1782 & 18.00 & 12.18 & 1 & 0 \\
\hline 1783 & 21.50 & 14.54 & 1.5 & 0 \\
\hline 1784 & 26.00 & 19.23 & 1.5 & 0 \\
\hline 1785 & 26.00 & 14.51 & 1.5 & 0 \\
\hline 1786 & 30.00 & 16.60 & 1.5 & 0 \\
\hline 1787 & 37.00 & 18.74 & 1.5 & 2 \\
\hline 1788 & 35.00 & 18.00 & 1 & 0.75 \\
\hline
\end{tabular}

${ }^{a}$ The year indicates the season in which the wheat was harvested (e.g. year 1785 corresponds to season 178485).

${ }^{\mathrm{b}}$ Wheat prices were taken in January and refer to wheat production of the previous season. Prices referenced to cost of living in Seville. Dates and figures in bold print point out years with a high wheat price.

${ }^{\mathrm{c}}$ References bunt index (national): out of the period 1755-1801 (0); within the period of references to common bunt (1755-1801) (0.5); references to bunt outbreak years (1770, 1781-99) (1); references to more specific bunt outbreak years $(1783-87,1790)(1.5)$.

${ }^{\mathrm{d}}$ Rainfall bunt index (from the excessive rain events between November and May): catastrophic flooding (value 0.5); extraordinary flooding with disturbing but not destructive river overflows (0.75); pro serenitate rogations or river floods with periods of persistent rains (1); extreme rain events from November, December, and January received a value +1 .

Sources: Llopis and Jerez (2001); Llopis et al. (2009); data to calculate the rainfall bunt index were taken from Table 3. 